\title{
Selective Oxygenation of lonones and Damascones by Fungal Peroxygenases
}

\author{
Esteban D. Babot, Carmen Aranda, José C. del Río, René Ullrich, Jan Kiebist, Katrin Scheibner, \\ Martin Hofrichter, Angel T. Martínez, and Ana Gutiérrez*
}

Cite This: J. Agric. Food Chem. 2020, 68, 5375-5383

Read Online

ABSTRACT: Apocarotenoids are among the most highly valued fragrance constituents, being also appreciated as synthetic building blocks. This work shows the ability of unspecific peroxygenases (UPOs, EC1.11.2.1) from several fungi, some of them being described recently, to catalyze the oxyfunctionalization of $\alpha$ - and $\beta$-ionones and $\alpha$ - and $\beta$-damascones. Enzymatic reactions yielded oxygenated products such as hydroxy, oxo, carboxy, and epoxy derivatives that are interesting compounds for the flavor and fragrance and pharmaceutical industries. Although variable regioselectivity was observed depending on the substrate and enzyme, oxygenation was preferentially produced at the allylic position in the ring, being especially evident in the reaction with $\alpha$-ionone, forming 3hydroxy- $\alpha$-ionone and/or 3-oxo- $\alpha$-ionone. Noteworthy were the reactions with damascones, in the course of which some UPOs oxygenated the terminal position of the side chain, forming oxygenated derivatives (i.e., the corresponding alcohol, aldehyde, and carboxylic acid) at C-10, which were predominant in the Agrocybe aegerita UPO reactions, and first reported here.

KEYWORDS: aromas, apocarotenoids, ionones, damascones, peroxygenases, biocatalysis, UPO

\section{INTRODUCTION}

Apocarotenoids or norisoprenoids, which are usually formed by partial oxidative degradation of carotenoids, include a wide range of compounds with different chemical structures and biological activities. Among these compounds, those having thirteen carbon atoms, such as ionones and damascones, are essential constituents of the aroma of tea, grapes, roses, tobacco, and wine and are also relevant flavors or fragrances that constitute an important economic resource for chemical industries. ${ }^{1}$ Moreover, damascones and their derivatives have also been identified as a novel class of potential cancer chemopreventive phytochemicals. ${ }^{2}$

The introduction of hydroxyl or keto functionalities in these compounds reduces their volatility and increases the longlasting odor. ${ }^{3}$ Most of these derivatives (3-hydroxy and 3-oxo$\alpha$-ionone, 4-hydroxy- and 4-oxo- $\beta$-ionone, and hydroxy- $\beta$ damascone isomers) are present in plants but in very small amounts and extraction is not a viable process for their industrial use. For this reason, they are usually prepared by chemical synthesis and, therefore, alternative methods for the bioproduction of these compounds are of high industrial interest. $^{1}$

Biotransformation of $\alpha$ - and $\beta$-ionones, and their respective $\alpha$ - and $\beta$-damascone isomers, to a number of hydroxy and keto derivatives has been reported for several fungi. ${ }^{3-7}$ However, microbial biotransformations require long incubation times, and often suffer from low conversion rates and substrate partial degradation. On the other hand, biotransformations with isolated enzymes (enzymatic in vitro conversion), such as some cytochrome P450 monooxygenases (P450s), ${ }^{8-10}$ including engineered P450 BM-3 variants, ${ }^{11,12}$ have also been reported. Most P450s, however, have the disadvantages of requiring expensive cofactors and auxiliary enzymes, and their stability is usually low due to their intracellular nature.

Unspecific peroxygenases (UPOs, EC.1.11.2.1) represent a relatively new and appealing type of biocatalysts for organic synthesis that, unlike P450s, are extracellular enzymes (therefore more stable) and only require $\mathrm{H}_{2} \mathrm{O}_{2}$ for activation. ${ }^{13}$ However, in spite of all recent progress in our understanding of UPO catalysis and application, ${ }^{14}$ some difficulties in UPO application are yet to be solved. They include, in addition to inactivation by hydrogen peroxide that affects enzyme reuse, the present limitations to heterologously express UPOs in bacterial systems (and even in fungal systems) due to the more recent discovery of these enzymes and their fungal origin. The latter aspects, to be overcome in the future, currently limit enzyme engineering to tailor UPOs for specific substrates and processes, as well as their production scale-up. UPOs have been shown to catalyze a diversity of interesting oxygenation reactions with aromatic substrates, ${ }^{15,16}$ aliphatic compounds, such as fatty acids, alkanes, fatty alcohols, ${ }^{17-21}$ steroids, and secosteroids, ${ }^{2-24}$ and other flavor and fragrance compounds, such as isophorone. ${ }^{25}$ The first UPO was described in the basidiomycetous fungus Agrocybe aegerita (AaeUPO), ${ }^{26}$ and since then, several other UPO enzymes have been purified from other Basidiomycota and Ascomycota species, such as Coprinellus radians, ${ }^{27}$ Marasmius rotula (MroUPO), ${ }^{28}$ and

Received: February 13, 2020

Revised: April 13, 2020

Accepted: April 15, 2020

Published: April 15, 2020

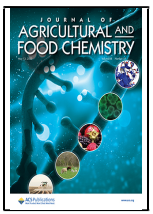


Chaetomium globosum (CglUPO), ${ }^{29}$ which are indicative of their widespread occurrence in the fungal kingdom. In addition to these wild-type (i.e., nonrecombinant) enzymes, there are other UPOs, e.g., from Coprinopsis cinerea $(\mathrm{rCciUPO})^{18}$ and Humicola insolens (rHinUPO), ${ }^{29}$ which are only known as recombinant proteins heterologously expressed by Novozymes A/S (Bagsvaerd, Denmark) in the mold Aspergillus oryzae. ${ }^{30}$ Very recently, a new UPO from the ascomycetous mold Daldinia caldariorum has become available from Novozymes, after gene expression in $A$. oryzae, being also expressible in Escherichia coli as a soluble and active enzyme. ${ }^{31}$

In the present work, the oxygenation of $\alpha$ - and $\beta$-ionones and their respective isomers $\alpha$ - and $\beta$-damascones by several UPOs is shown for the first time. These are new reactions of interest for the biotechnological synthesis of different natural flavors, pharmaceuticals, and synthetic building blocks to be added to the existing portfolio of reactions catalyzed by these exciting enzymes. ${ }^{14}$

\section{MATERIALS AND METHODS}

Enzymes. AaeUPO (isoform II), a wild UPO from cultures of $A$. aegerita TM-A1 (syn. Cyclocybe aegerita, DSM 22459) grown in soybean-peptone medium, was purified as previously described. ${ }^{26}$ MroUPO is another wild-type UPO, from cultures of M. rotula DSM25031 (German Collection of Microorganisms and Cell Cultures, Braunschweig), which was purified as described by Gröbe et al. ${ }^{28} \mathrm{CglUPO}$, the third wild-type UPO originates from cultures of C. globosum DSM-62110, which was purified as recently described. ${ }^{29}$ $\mathrm{rCciUPO}$ corresponds to the protein model 7249 from the sequenced C. cinerea genome available at the JGI (http://genome.jgi.doe.gov/ Copcil). The recombinant enzymes rCciUPO ( $44 \mathrm{kDa}), \mathrm{rHinUPO}$, and $\mathrm{rDcaUPO}$ were provided by Novozymes $\mathrm{A} / \mathrm{S}$ after expression in A. oryzae. ${ }^{30}$ All UPO proteins were purified by fast protein liquid chromatography (FPLC) using a combination of size exclusion chromatography (SEC) and ion-exchange chromatography on different anion and cation exchangers. Purification was confirmed by sodium dodecyl sulfate-polyacrylamide gel electrophoresis (SDSPAGE) and ultraviolet-visible (UV-vis) spectroscopy following the characteristic heme-maximum around $420 \mathrm{~nm}$ (Soret band of restingstate UPOs). Enzyme concentration was estimated according to the characteristic UV-vis band of the reduced UPO complex $\left(\mathrm{Fe}^{2+}\right.$. heme) with carbon monoxide. ${ }^{32}$

Chemical Compounds. Ionones, rac-(3E)-4-(2,6,6-trimethyl-2cyclohexen-1-yl)-3-buten-2-one (also known as $\alpha$-ionone) and (3E)4-(2,6,6-trimethyl-1-cyclohexen-1-yl)-3-buten-2-one (also known as $\beta$-ionone), and damascones, rac-(2Z)-1-(2,6,6-trimethyl-2-cyclohexen-1-yl)-2-buten-1-one (also known as $\alpha$-damascone) and (2E)-1(2,6,6-trimethyl-1-cyclohexen-1-yl)-2-buten-1-one (also known as $\beta$ damascone) were tested as substrates of the above UPOs. All of the compounds were purchased from Sigma-Aldrich except for $\alpha$-ionone that was supplied by Fluka.

Enzymatic Reactions. Reactions ( $1 \mathrm{~mL}$ volume) with ionones and damascones $(0.5 \mathrm{mM})$ were performed at $30{ }^{\circ} \mathrm{C}$, in $50 \mathrm{mM}$ phosphate buffer, $\mathrm{pH} 7.0$ (pH 5.5 in MroUPO reaction). The enzyme concentration was $0.5 \mu \mathrm{M}$, and the $\mathrm{H}_{2} \mathrm{O}_{2}$ was added every 6 min in doses of $0.5 \mu \mathrm{mol}$ to a final concentration of $2.5 \mathrm{mM}^{25}$ In control experiments, the substrates were treated under the same conditions (including $\mathrm{H}_{2} \mathrm{O}_{2}$ ) but without the enzyme. The blank experiments did not give any oxidation product. Samples, at $30 \mathrm{~min}$ reaction, were extracted with ethyl acetate and directly analyzed by gas chromatography-mass spectrometry (GC-MS). On the other hand, a time-course experiment with all substrates and enzymes was performed, and the corresponding samples within several reaction times $(5,10,15$, and $20 \mathrm{~min})$ were analyzed by GC-MS. In addition, the samples were dried under $\mathrm{N}_{2}$ to prepare trimethylsilyl (TMS) derivatives with $\mathrm{N}, \mathrm{O}$-bis(trimethylsilyl)trifluoroacetamide (Supelco) that were also analyzed by GC-MS. Reactions with a higher substrate concentration were also performed using $5 \mathrm{mM}$ of $\beta$-ionone, $1 \mu \mathrm{M}$ of enzyme, and by adding $\mathrm{H}_{2} \mathrm{O}_{2}$ with a syringe pump over $6 \mathrm{~h}$ at $3 \mu \mathrm{mol}$ $\mathrm{h}^{-1}$. The total turnover number (TTN) (mol product $\times$ number of conversions/mol enzyme) as well as the total turnover frequency (TOF) (TTN/time) were calculated in these reactions.

GC-MS Analyses. The analyses of samples (with and without silylation) were performed in a Shimadzu GC-MS QP 2010 Ultra system, using a fused-silica DB-5HT capillary column $(30 \mathrm{~m} \times 0.25$ $\mathrm{mm}$ internal diameter, $0.1 \mu \mathrm{m}$ film thickness) from J\&W Scientific. The oven was heated from $50{ }^{\circ} \mathrm{C}(1.5 \mathrm{~min})$ to $90{ }^{\circ} \mathrm{C}(2 \mathrm{~min})$ at 30 ${ }^{\circ} \mathrm{C} \mathrm{min}{ }^{-1}$, and then from 90 to $250{ }^{\circ} \mathrm{C}(15 \mathrm{~min})$ at $8{ }^{\circ} \mathrm{C} \mathrm{min}{ }^{-1}$. The injection was performed at $250^{\circ} \mathrm{C}$, and the transfer line was kept at $300{ }^{\circ} \mathrm{C}$. Compounds were identified by mass fragmentography and by comparing their mass spectra with those of the Wiley and NIST libraries, and those previously reported, ${ }^{3,4,7,9,10,33-35}$ and relative quantification was obtained from the total-ion peak area, using response factors of the same (in the case of substrates) or similar compounds. The mass spectra and chemical structures of substrates and their reaction products (underivatized and as TMS derivatives) are included in the Supporting Information (Table S1).

\section{RESULTS AND DISCUSSION}

In the present work, several fungal UPOs, such as AaeUPO, MroUPO, CglUPO, rCciUPO, rHinUPO, and rDcaUPO, were tested for their ability to oxygenate apocarotenoids such as $\alpha$ ionone, $\beta$-ionone, $\alpha$-damascone, and $\beta$-damascone (Figures 1-4), using $\mathrm{H}_{2} \mathrm{O}_{2}$ as a cosubstrate and an $\mathrm{O}$ donor. The

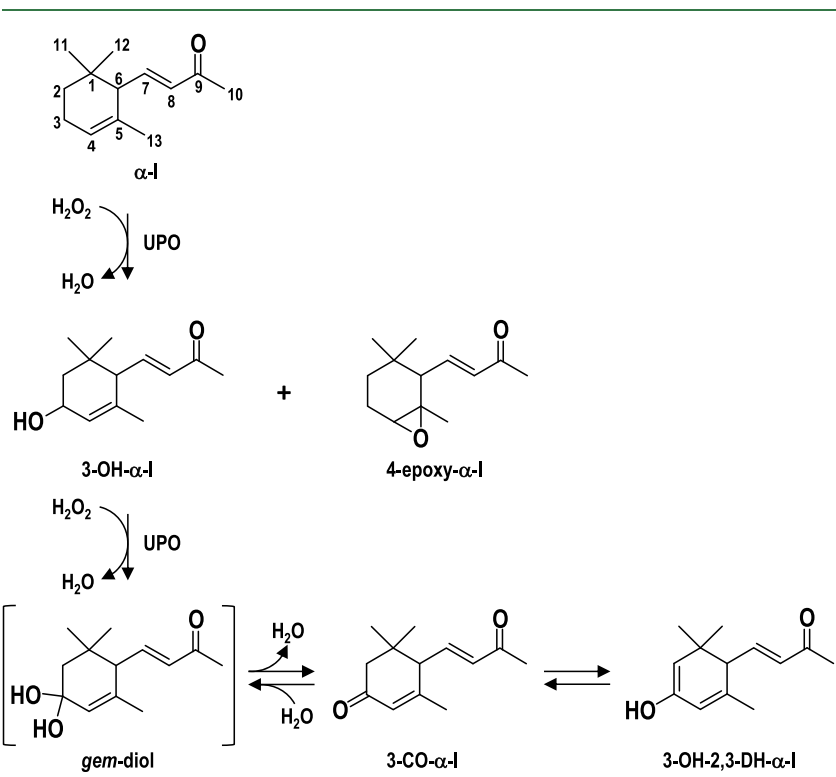

Figure 1. $\alpha$-Ionone $(\alpha-\mathrm{I})$ oxygenation by UPOs, showing 3-hydroxy$\alpha$-ionone (3-OH- $\alpha$-I) and 3-oxo- $\alpha$-ionone (3-CO- $\alpha$-I) formed via a gem-diol intermediate, its tautomer 3-hydroxy-2,3-didehydro- $\alpha$ ionone (3-OH-2,3-DH- $\alpha$-I) and 4-epoxy- $\alpha$-ionone (4-epoxy- $\alpha$-I).

performance of enzymatic reactions was evaluated by GC-MS, and the different activities and selectivities attained by the UPOs are described and discussed in the following sections.

Reactions with $\boldsymbol{\alpha}$-lonone. All UPOs were capable of completely transforming $\alpha$-ionone within $30 \mathrm{~min}$ reaction time, except for $\mathrm{rCciUPO}$ that only reached $21 \%$ conversion under these conditions (Table 1). The time course of the reactions showed that $\mathrm{rHin} \mathrm{UPO}$ and $\mathrm{rDcaUPO}$ completely converted the substrate within $5 \mathrm{~min}$, while AaeUPO, MroUPO, and CglUPO needed 15-30 min (Figure 5A).

GC-MS analyses of enzymatic reactions revealed that all enzymes selectively $(86-98 \%)$ oxygenated $\alpha$-ionone at C-3 
<smiles>CC(=O)/C=C/C1=C(C)CCCC1(C)C</smiles>

Figure 2. $\beta$-Ionone $(\boldsymbol{\beta}$-I) oxygenation by UPOs showing the different oxygenated derivatives: 4-hydroxy- $\beta$-ionone $(4-\mathrm{OH}-\boldsymbol{\beta}$-I $)$, 3-hydroxy- $\beta$-ionone (3-OH- $\beta$-I), 2 -hydroxy- $\beta$-ionone (2-OH- $\beta$-I), 10-hydroxy- $\beta$-ionone (10-OH- $\beta$-I), 13 -hydroxy- $\beta$-ionone (13-OH- $\beta$-I), 4-oxo- $\beta$-ionone $(4-\mathrm{CO}-\beta$ I), 2-oxo- $\beta$-ionone (2-CO- $\beta$-I), 7,11-epoxymegastigma-5(6)-en-9-one (EME), and 4-hydroxy-7,11-epoxymegastigma-5(6)-en-9-one (4-OH-EME).

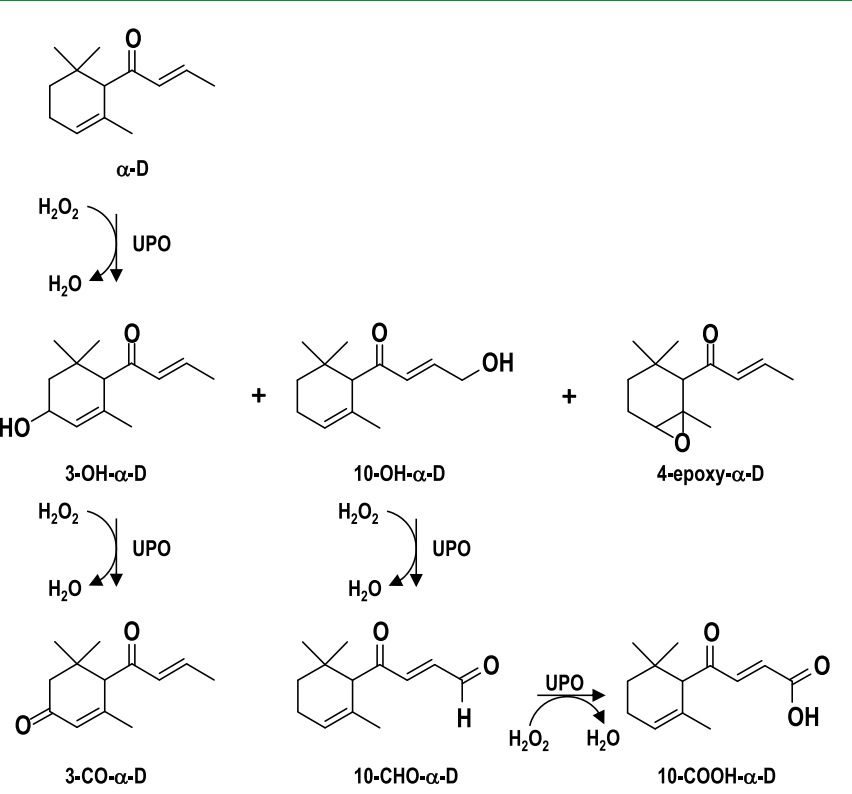

Figure 3. $\alpha$-Damascone $(\boldsymbol{\alpha}$-D) oxygenation by UPOs, showing 3hydroxy- $\alpha$-damascone (3-OH- $\alpha$-D), 10-hydroxy- $\alpha$-damascone (10OH- $\alpha$-D), 4-epoxy- $\alpha$-damascone (4-epoxy- $\alpha$-D), 3-oxo- $\alpha$-damascone (3-CO- $\alpha$-D), 4-oxo-4-(2,6,6-trimethylcyclohex-2-en-1-yl)but-2-enal (10-CHO- $\alpha$-D), and 4-oxo-4-(2,6,6-trimethylcyclohex-2-en-1-yl)but2 -enoic acid (10-COOH- $\boldsymbol{\alpha}$-D) derivatives.

(allylic position) producing 3-hydroxy- $\alpha$-ionone (3-OH- $\alpha$-I) and 3-oxo- $\alpha$-ionone (3-CO- $\boldsymbol{\alpha}$-I) (Table 1, Figures 1 and S1). In addition to these derivatives, the tautomer of the keto derivative, 3-hydroxy-2,3-didehydro- $\alpha$-ionone (3-OH-2,3-DH$\boldsymbol{\alpha}-\mathrm{I})(7 \%)$, was observed in $\mathrm{rHinUPO}$ reactions. Small amounts $(1-14 \%)$ of 4 -epoxy- $\alpha$-ionone (4-epoxy- $\alpha$-I) were also detected in all reactions. The mass spectra of these compounds (Table S1) were in agreement with those published in the NIST library and the literature. ${ }^{7,9,10}$

Different proportions of both cis-3-OH- $\boldsymbol{\alpha}$-I and trans-3-OH$\boldsymbol{\alpha}$-I isomers were observed in the reactions with the different<smiles>C/C=C/C(=O)C1=C(C)CCCC1(C)C</smiles><smiles>C/C=C/C(=O)C1=C(C)CC(O)CC1(C)C</smiles><smiles>C/C=C/C(=O)C1=C(C)C(=O)CCC1(C)C</smiles><smiles>CC1=C(C(=O)O)C(C)(C)CCC1</smiles><smiles>CC1=C(C(=O)OCC(=O)O)C(C)(C)CCC1</smiles>

Figure 4. $\beta$-Damascone $(\boldsymbol{\beta}$-D) oxygenation by UPOs showing 3hydroxy- $\beta$-damascone (3-OH- $\beta$-D), 4-hydroxy- $\beta$-damascone (4-OH$\boldsymbol{\beta}$-D), and 10-hydroxy- $\beta$-damascone (10-OH- $\boldsymbol{\beta}$-D), and the overoxygenated compounds 4-oxo- $\beta$-damascone (4-CO- $\beta$-D), 4-oxo-4(2,6,6-trimethylcyclohex-1-en-1-yl)but-2-enal (10-CHO- $\beta$-D), and 4oxo-4-(2,6,6-trimethylcyclohex-1-en-1-yl)but-2-enoic acid (10COOH- $\beta$-D).

UPOs, the trans-diastereoisomer being generally the most abundant, except in AaeUPO reactions where the proportion of both isomers was similar (Figures 6A and S1) after $30 \mathrm{~min}$. The higher proportion of the trans-diastereoisomer may be attributed to the faster further oxygenation of the cisdiastereoisomer by these enzymes via a gem-diol intermediate that is in equilibrium with the corresponding keto derivative (Figure 1), ${ }^{17}$ although an enzymatic preference for hydrox- 
Table 1. Conversion (Percentage of Substrate Transformed) of $\alpha$-Ionone $(\alpha-\mathrm{I})$ by Several UPOs (30 min) and Abundance (Relative Percentage) of the Reaction Products, Including Hydroxy (OH), Keto (CO), and Epoxy Derivatives

\begin{tabular}{|c|c|c|c|c|c|c|}
\hline & AaeUPO & MroUPO & $\mathrm{rCciUPO}$ & CglUPO & rHinUPO & $\mathrm{rDcaUPO}$ \\
\hline $\begin{array}{l}\text { conversion (\%) } \\
\text { products }(\%)\end{array}$ & $>99$ & $>99$ & 21 & $>99$ & $>99$ & $>99$ \\
\hline $3-\mathrm{OH}-\alpha-\mathrm{I}$ & 93 & 55 & 63 & 72 & 1 & 45 \\
\hline $3-\mathrm{CO}-\alpha-\mathrm{I}$ & 5 & 31 & 35 & 22 & $98^{a}$ & 53 \\
\hline 4-epoxy- $\alpha$-I & 2 & 14 & 2 & 6 & 1 & 2 \\
\hline
\end{tabular}

${ }^{a}$ Including the keto derivative (91\%) and its tautomer 3-hydroxy-2,3-didehydro- $\alpha$-ionone (7\%).

A

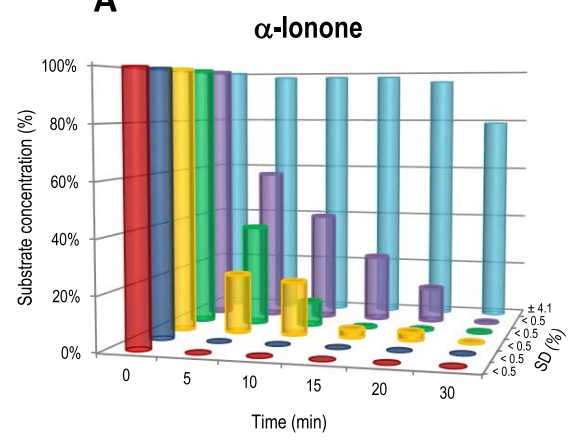

C

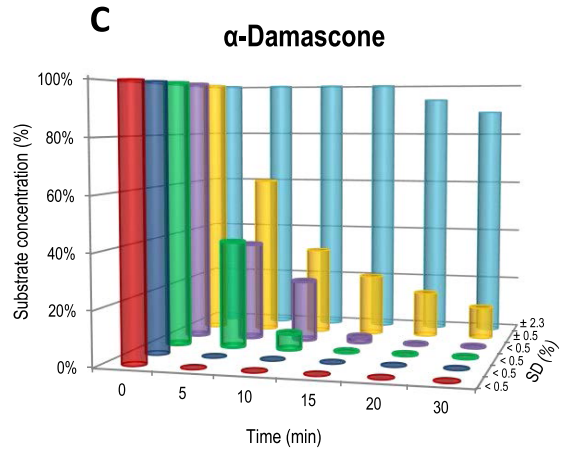

AaeUPO MroUPO $=$ rCciuPO
B

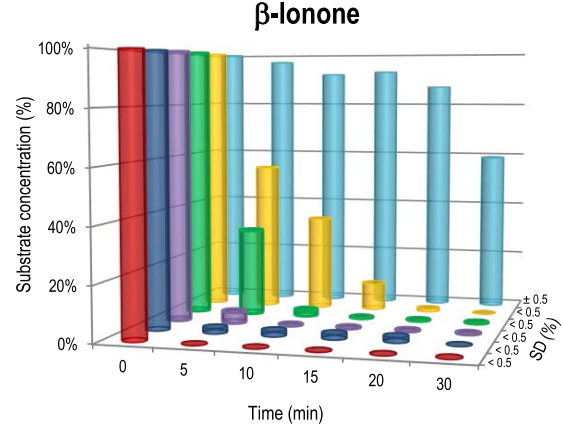

D

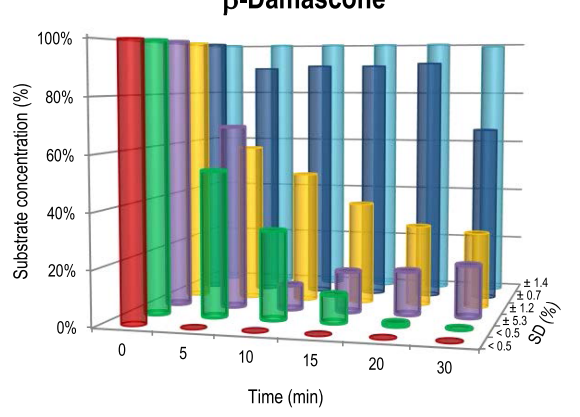

$\beta$-Damascone

Cg/UPO rHinUPO rDcaUPO

Figure 5. Time course of the transformation of $0.5 \mathrm{mM} \alpha$-ionone (A), $\beta$-ionone (B), $\alpha$-damascone (C), and $\beta$-damascone (D) by $0.5 \mu \mathrm{M}$ Aae UPO (purple), MroUPO (yellow), rCciUPO (light blue), CglUPO (green), rHinUPO (red), and rDcaUPO (blue). The standard deviations (SD) calculated for duplicates (at $30 \mathrm{~min}$ ) are indicated.

ylation of $\alpha$-ionone to the corresponding cis or trans diastereomers may not be discarded.

Interestingly, all UPOs were able to over-oxygenate 3-OH$\boldsymbol{\alpha}$-I to form 3-CO- $\boldsymbol{\alpha}$-I (via the gem-diol), except for AaeUPO that only formed $5 \%$ of the latter compound (Table 1 ). The low over-oxygenating activity of AaeUPO for hydroxy derivatives was also observed in the hydroxylation of the related $\alpha$-isophorone. ${ }^{25}$ The contrary was observed in $\mathrm{rHin} \mathrm{UPO}$ reactions, in which 3-CO- $\boldsymbol{\alpha}$-I was the predominant product and the $\mathrm{OH}$-tautomer was also observed. The reason why the enol form was only found in $\mathrm{rHinUPO}$ reactions may be due to the high amount of the keto-form in these reactions. With other UPOs, the lower amount of 3-CO- $\boldsymbol{\alpha}$-I formed may be the reason for the $\mathrm{OH}$-tautomer to be below the detection limit.

Similar oxygenated derivatives were reported for fungimediated biotransformation of $\alpha$-ionone, although generally with lower substrate conversion rates. ${ }^{3,5,7}$ On the other hand, the biotransformation of $\alpha$-ionone catalyzed by $\mathrm{P} 450$ CYP109D1 showed the regioselective formation of 3-OH- $\alpha$ I. ${ }^{9}$ The selectivity found here for most UPOs is similar to that reported for cytochrome CYP101B1, where the transdiastereoisomer was preferentially obtained $(66 \%) .{ }^{10}$

Reactions with $\boldsymbol{\beta}$-Ionone. All UPOs were able to completely convert $\beta$-ionone under the same conditions within $30 \mathrm{~min}$ of reaction, except for $\mathrm{rCciUPO}$ that only reached $41 \%$ conversion (Table 2). Time courses of the reactions show similar conversion degrees as those observed with $\alpha$-ionone for the different UPOs, with the exception of AaeUPO, which achieved almost complete substrate conversion within just 5 min (Figure 5B). On the other hand, different regioselectivities were noticed for the different UPOs tested, and oxygenation occurred at different positions (Table 2, Figures 2 and S2). CglUPO and rHinUPO were most selective (around 80\% regioselectivity) toward the $\mathrm{C}-4$ position, resulting in the formation of 4-hydroxy- $\beta$-ionone (4-OH- $\beta$-I) and its overoxygenated (via a gem-diol intermediate) derivative 4-oxo- $\beta$ ionone (4-CO- $\beta$-I). All UPOs oxygenated, in addition to C-4, other ring positions (C-2 and C-3), although to a lesser extent. These compounds were tentatively identified by MS, and their mass spectra (Table S1) matched with those published in the NIST library and literature..$^{9,10,12,35,36}$ Moreover, other 

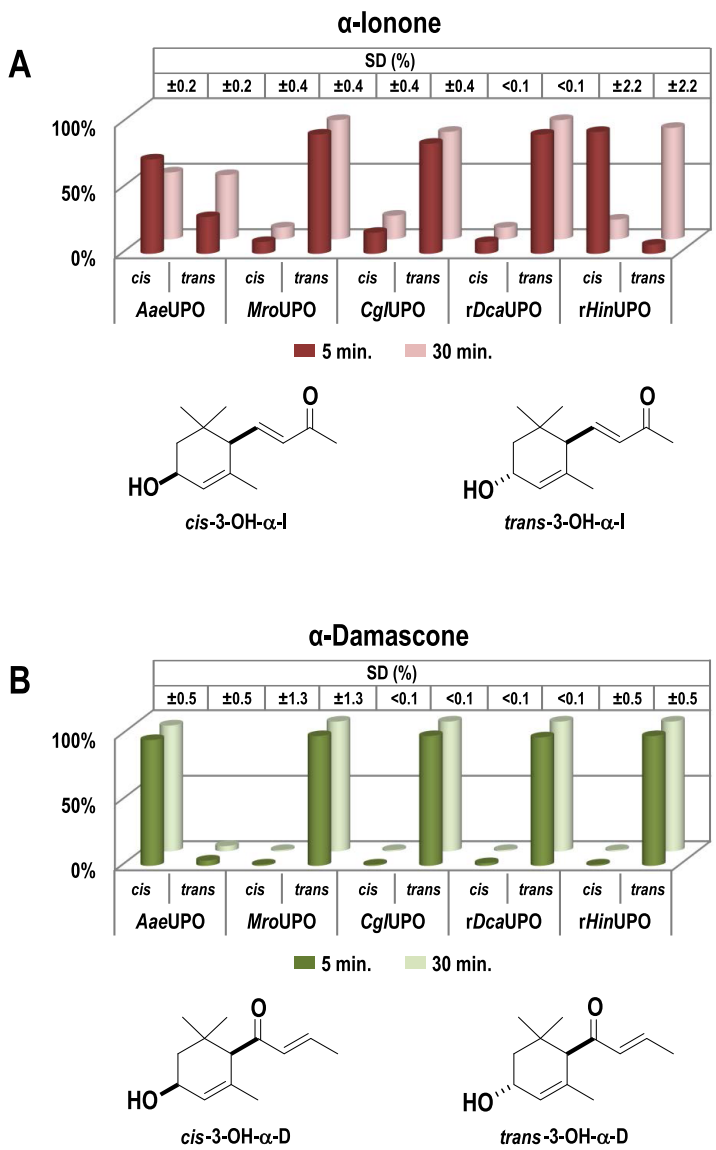

Figure 6. Abundance (relative percentage) and chemical structures (relative configuration) of the different diastereoisomers formed in the reactions at 5 and $30 \mathrm{~min}$ of $\alpha$-ionone (A) and $\alpha$-damascone (B) with several UPOs. The standard deviations (SD) calculated for duplicates (at $30 \mathrm{~min}$ ) are indicated.

hydroxylated derivatives resulting from a second and third oxygenation step (dihydroxy and/or hydroxy-keto derivatives, Figures S2 and S3) were also detected in almost all reactions.

Only in the case of $\mathrm{rCciUPO}$, the oxygenation of the terminal C-10 position in the side chain (10-hydroxy- $\beta$-ionone, 10-OH- $\boldsymbol{\beta}$-I) was observed (Figure S2C). The position of the hydroxyl group was determined by the mass spectrum of the TMS derivative that showed a major peak at $\mathrm{m} / z \quad 177$ corresponding to the loss of the terminal hydroxyl group (Figure S4A). This compound was only evidenced in the silylated sample. To the best of our knowledge, the occurrence of this oxygenated derivative has not been reported so far. The terminal oxygenation of side chains of other aliphatic cyclic compounds by UPOs has been described for steroids, secosteroids, and trans- $\beta$-methylstyrene. ${ }^{22,23,37}$

On the other hand, the presence of 7,11-epoxymegastigma5(6)-en-9-one (EME) and its hydroxylated derivative 4hydroxy-7,11-epoxymegastigma-5(6)-en-9-one (4-OH-EME) was only observed in the reaction with $\mathrm{rDcaUPO}$ (Figures 2 and $\mathrm{S} 2 \mathrm{~F}$ ), and to the best of our knowledge, not reported so far for P450s or microbial cultures. This unusual bicyclic ionone derivative would be formed by the oxygenation of the C-13, followed by ring closure between positions 7 and 13 of the ionone framework as reported for the chemical synthesis of EME (in several steps) starting from racemic $\gamma$-ionone epoxidation. ${ }^{33}$ The presence of the hydroxylated derivative of $\beta$-ionone at $\mathrm{C}-13$ (Figures $\mathrm{S} 2 \mathrm{~F}$ and $\mathrm{S} 4 \mathrm{~B}$ ) supports this mechanism. Moreover, the absence of the dihydroxylated derivative of $\beta$-ionone at $\mathrm{C}-4$ and $\mathrm{C}-13$ suggests that $4-\mathbf{O H}$ EME is not formed from 4-hydroxy- $\beta$-ionone although this could not be absolutely discarded.

Finally, reactions with higher substrate $(5 \mathrm{mM})$ and enzyme $(1 \mu \mathrm{M})$ loading were also performed, in which the cosubstrate $\mathrm{H}_{2} \mathrm{O}_{2}$ was continuously supplied over $6 \mathrm{~h}$ with a syringe pump to preserve the enzyme stability (that is decreased by high local concentrations of peroxide). Under these conditions, nearly complete substrate conversion (except with $\mathrm{rDcaUPO}$ ) and slightly increased selectivity were achieved, taking into account that five times less enzyme/substrate ratio was used. This way, the total turnover numbers of 1700-6200 were reached (Table 3).

Reactions with $\alpha$-Damascone. All UPOs tested transformed the substrate to great extents $(88-100 \%)$ within 30 min, except for $\mathrm{rCciUPO}$ that only accomplished $11 \%$ conversion under the same conditions (Table 4). The time course of the reaction showed that $\mathrm{rHin} \mathrm{UPO}$ and $\mathrm{rDcaUPO}$ were more efficient than the other UPOs since they completely transformed the substrate within $5 \mathrm{~min}$ of the reaction (Figure 5C).

All UPOs (except for $\mathrm{rCciUPO}$ ) oxygenated the C-3 position to produce 3-hydroxy- $\alpha$-damascone (3-OH- $\alpha$-D) (Table 4, Figures 3 and S5). In a similar way as in the

Table 2. Conversion (Percentage of Substrate Transformed) of $\beta$-lonone $(\boldsymbol{\beta}$-I) by Several UPOs (30 min) and Abundance (Relative Percentage) of the Reaction Products, Including Hydroxy $(\mathrm{OH})$ and Keto (CO) Derivatives, and/or 7,11Epoxymegastigma-5(6)-en-9-one (EME), and Dihydroxy or Hydroxy-Keto Derivatives of $\beta$-I (Others)

\begin{tabular}{|c|c|c|c|c|c|c|}
\hline & AaeUPO & MroUPO & $\mathrm{rCciUPO}$ & CgluPO & rHinUPO & $\mathrm{rDcaUPO}$ \\
\hline $\begin{array}{l}\text { conversion (\%) } \\
\text { products (\%) }\end{array}$ & $>99$ & $>99$ & 41 & $>99$ & $>99$ & $>99$ \\
\hline $4-\mathrm{OH}-\beta-\mathrm{I}$ & 55 & 55 & 61 & 64 & 21 & 53 \\
\hline 3-OH- $\beta$-I & 22 & & 19 & & & 19 \\
\hline $2-\mathrm{OH}-\beta-\mathrm{I}$ & 13 & 7 & 2 & 1 & & 3 \\
\hline $10-\mathrm{OH}-\beta-\mathrm{I}$ & & & 14 & & & \\
\hline $13-\mathrm{OH}-\beta-\mathrm{I}$ & & & & & & 7 \\
\hline EME & & & & & & 11 \\
\hline $2-\mathrm{CO}-\beta-\mathrm{I}$ & & 18 & & & & \\
\hline $4-\mathrm{CO}-\beta-\mathrm{I}$ & 3 & 1 & 2 & 20 & 58 & \\
\hline 4-OH-EME & & & & & & 5 \\
\hline others & 7 & 19 & 2 & 15 & 21 & 2 \\
\hline
\end{tabular}


Table 3. Conversion (Percentage of Substrate Transformed), Abundance (Relative Percentage) of Reaction Products, Including Hydroxy (OH), Keto (CO), and Dihydroxy or Hydroxy-Keto Derivatives (others), Total Turnover Number (TTN), and Total Turnover Frequency (TOF) in the Enzymatic Transformation of $5 \mathrm{mM} \beta$-Ionone $(\beta$-I)

\begin{tabular}{|c|c|c|c|c|c|c|}
\hline & AaeUPO & MroUPO & $\mathrm{rCciUPO}$ & CglUPO & rHinUPO & $\mathrm{rDcaUPO}$ \\
\hline conversion (\%) & 95 & 93 & 22 & 98 & 91 & 52 \\
\hline \multicolumn{7}{|l|}{ products (\%) } \\
\hline $4-\mathrm{OH}-\beta-\mathrm{I}$ & 87 & 67 & 83 & 70 & 57 & 54 \\
\hline $4-\mathrm{CO}-\beta-\mathrm{I}$ & & 13 & & 24 & 24 & \\
\hline others & 13 & 20 & 17 & 6 & 19 & 46 \\
\hline TTN & 5200 & 5900 & 1700 & 6200 & 6000 & 2800 \\
\hline TOF $\left(\min ^{-1}\right)$ & 14 & 16 & 5 & 17 & 17 & 8 \\
\hline
\end{tabular}

Table 4. Conversion (Percentage of Substrate Transformed) of $\alpha$-Damascone $(\alpha$-D) by Several UPOs (30 min) and Abundance (Relative Percentage) of the Reaction Products, Including Hydroxy (OH), Aldehyde (CHO), Keto (CO), Carboxy $(\mathrm{COOH})$, and Epoxy Derivatives

\begin{tabular}{|c|c|c|c|c|c|c|}
\hline & AaeUPO & MroUPO & $\mathrm{rCciUPO}$ & CglUPO & rHinUPO & $\mathrm{rDcaUPO}$ \\
\hline conversion (\%) & $>99$ & 88 & 11 & $>99$ & $>99$ & $>99$ \\
\hline \multicolumn{7}{|l|}{ products (\%) } \\
\hline $3-\mathrm{OH}-\alpha-\mathrm{D}$ & 18 & 55 & & 68 & 27 & 83 \\
\hline 4-epoxy- $\alpha$-D & & 6 & & 16 & 3 & 4 \\
\hline $10-\mathrm{OH}-\alpha-\mathrm{D}$ & & 6 & 41 & & & \\
\hline 3-CO- $\alpha-\mathrm{D}$ & & & & 16 & 70 & 13 \\
\hline $10-\mathrm{CHO}-\alpha-\mathrm{D}$ & 2 & 14 & 52 & & & \\
\hline $10-\mathrm{COOH}-\alpha-\mathrm{D}$ & 80 & 19 & 7 & & & \\
\hline
\end{tabular}

Table 5. Conversion (Percentage of Substrate Transformed) of $\beta$-Damascone $(\beta$-D) by Several UPOs (30 min) and Abundance (Relative Percentage) of the Reaction Products, Including Hydroxy (OH), Aldehyde (CHO), Keto (CO), Carboxy $(\mathrm{COOH})$, and Epoxy Derivatives

\begin{tabular}{|c|c|c|c|c|c|c|}
\hline & AaeUPO & MroUPO & $\mathrm{rCciUPO}$ & CglUPO & rHinUPO & $\mathrm{rDcaUPO}$ \\
\hline conversion (\%) & 81 & 72 & 1 & $>99$ & $>99$ & 34 \\
\hline \multicolumn{7}{|l|}{ products (\%) } \\
\hline $3-\mathrm{OH}-\beta-\mathrm{D}$ & 32 & 8 & & 6 & 5 & 24 \\
\hline $4-\mathrm{OH}-\beta-\mathrm{D}$ & 9 & 46 & & 88 & 53 & 71 \\
\hline $10-\mathrm{OH}-\beta-\mathrm{D}$ & 3 & 6 & $>99$ & & & 5 \\
\hline $4-\mathrm{CO}-\beta-\mathrm{D}$ & & & & 6 & 42 & \\
\hline $10-\mathrm{CHO}-\beta$-D & 8 & 17 & & & & \\
\hline $10-\mathrm{COOH}-\beta-\mathrm{D}$ & 48 & 23 & & & & \\
\hline
\end{tabular}

reactions with $\alpha$-ionone, the hydroxylation of $\alpha$-damascone by several UPOs yielded both diastereoisomers, cis-3-OH- $\alpha-D$ and trans-3-OH- $\boldsymbol{\alpha}-\mathbf{D}$, whose mass spectra were in accordance with those previously reported. ${ }^{4}$ MroUPO, CglUPO, rDcaU$\mathrm{PO}$, and $\mathrm{rHin} \mathrm{UPO}$ were more selective, giving principally the trans-diastereoisomer, while AaeUPO mainly produced the cisdiastereoisomer (Figure 6B). In addition, CglUPO, rHinUPO, and $\mathrm{rDcaUPO}$ over-oxygenated 3-OH- $\boldsymbol{\alpha}$-D to the 3-oxo derivative, and most UPOs (MroUPO, CglUPO, rDcaUPO, and $\mathrm{rHinUPO}$ ) formed 4-epoxy- $\alpha$-damascone (4-epoxy- $\boldsymbol{\alpha}$-D) as well, although in minor amounts. Again, similar products were obtained in fungi-mediated biotransformation of $\alpha$ damascone but with lower conversion rates, maybe due to the toxicity of these compounds to fungal cultures. ${ }^{3}$

Interestingly, in addition to ring oxygenation, AaeUPO, MroUPO, and $\mathrm{rCciUPO}$ oxygenated the terminal position of the side chain (Figure 3 ) being the predominant reaction $(80 \%$ of the total products) for the former UPO (Table 4 and Figure S5). In these reactions, the formation of the terminal alcohol (10-hydroxy- $\alpha$-damascone, 10-OH- $\boldsymbol{\alpha}$-D) was followed by its over-oxygenation, producing the corresponding aldehyde (4oxo-4-(2,6,6-trimethylcyclohex-2-en-1-yl)but-2-enal, 10-CHO$\boldsymbol{\alpha}$-D) and the carboxylic acid (4-oxo-4-(2,6,6-trimethylcyclo- hex-2-en-1-yl)but-2-enoic acid, 10-COOH- $\boldsymbol{\alpha}$-D). These compounds were tentatively identified by the mass spectra of their TMS derivatives (Figure S6). The spectra show the molecular ions at $m / z 280$ (10-OH- $\boldsymbol{\alpha}$-D), $m / z 206$ (10-CHO- $\boldsymbol{\alpha}$-D), and $m / z 294(\mathbf{1 0 - C O O H}-\boldsymbol{\alpha}-\mathbf{D})$ as well as the fragments corresponding to the loss of a methyl group $\left[\mathrm{M}-\mathrm{CH}_{3}\right]^{+}$at $m / z 265,191$, and 279, respectively, and the fragment at $m / z$ 123 from the intact ring moiety. Additionally, diagnostic fragments at $m / z 157$, corresponding to the side chain butenoyl group in 10-OH- $\boldsymbol{\alpha}$-D (Figure S6A), and at $m / z$ 177 due to the loss of the aldehyde group $[\mathrm{M}-\mathrm{CHO}]^{+}$(Figure S6B) are also observed. To the best of our knowledge, such damascone derivatives at $\mathrm{C}-10$ have not been reported so far. This may be due to the fact that most authors analyzed these compounds without derivatization, and we found that they can only be detected after derivatization (silylation).

Reactions with $\boldsymbol{\beta}$-Damascone. Among all UPOs tested, only $\mathrm{Cgl \textrm {UPO }}$ and $\mathrm{rHinUPO}$ completely converted $\beta$ damascone within $30 \mathrm{~min}$, while AaeUPO, MroUPO, and $\mathrm{rDcaUPO}$ attained conversions of 81,72 , and $34 \%$, respectively, under the same conditions, and $\mathrm{rCciUPO}$ was practically incapable of oxidizing it (Table 5 and Figures 4, S7). Noteworthy is the low conversion of this compound by 
rDcaUPO compared to the other substrates tested. The time course of the reaction showed that $\mathrm{rHinUPO}$ was more efficient than the other UPOs since it completely transformed the substrate within 5 min (Figure 5D).

In most cases, the hydroxylation at the C-4 position was dominant over that at the C-3 position, with the exception of AaeUPO. On the other hand, rHinUPO and, to a minor extent, CglUPO were the only enzymes that over-oxygenated the 4OH- $\boldsymbol{\beta}$-D to 4-oxo- $\beta$-damascone (4-CO- $\boldsymbol{\beta}$-D) (Figures S7D and S7E). The mass spectra of these compounds (Table S1) are in agreement with those previously reported. ${ }^{3,34,36}$ On the other hand, as in $\alpha$-damascone reactions, oxygenated derivatives (alcohol, aldehyde, and carboxylic acid) at C-10 were also formed (Figure 4), preferentially by AaeUPO and MroUPO (Figure S7). These compounds were identified by the mass spectra of their TMS derivatives (Figure S8), which showed characteristic fragments similar to those of $\alpha$ damascone derivatives, as the molecular ions at $\mathrm{m} / z 280$ (10-OH- $\beta$-D), $m / z 206$ (10-CHO- $\beta$-D), and $m / z 294$ (10COOH- $\boldsymbol{\beta}$-D) and the fragments corresponding to the loss of a methyl group $\left[\mathrm{M}-\mathrm{CH}_{3}\right]^{+}$at $m / z 265,191$, and 279, respectively. Likewise, the fragment at $\mathrm{m} / z 177$ originated by the loss of the aldehyde group $[\mathrm{M}-\mathrm{CHO}]^{+}$(Figure S8B) is also observed.

Comparison of Oxygenation Patterns by Different UPOs. Generally, all UPOs accomplished high conversion rates for all substrates tested, except for $\mathrm{rCciUPO}$. $\mathrm{rHinUPO}$ and $\mathrm{rDcaUPO}$ were the most efficient ones (that converted more substrates in less time under the same conditions) in oxidizing all substrates tested (with the exception of $\beta$ damascone that was only moderately converted by $\mathrm{rDcaUPO}$ ) (Figure 5). On the other hand, AaeUPO showed higher efficiency with $\beta$-ionone than with any other substrate.

Regarding selectivity of the reactions with ionones, all UPOs showed higher regioselectivities (up to 99\%) with $\alpha$-ionone than with $\beta$-ionone (Tables 1 and 2). Although $\alpha$ - and $\beta$ ionones differ only in the position of the cyclohexene double bond, UPOs realized different reactivities toward them. Analyses of the different oxygenation products formed by the UPOs revealed that the position of the double bond in the cyclohexenyl ring had seemingly an effect on the regioselectivity of hydroxylation, directing it toward the allylic position. In this sense, $\alpha$ - and $\beta$-ionone were mainly hydroxylated by most UPOs at C-3 and C-4 to form 3-hydroxy- $\alpha$-ionone and 4hydroxy- $\beta$-ionone, respectively. However, this effect was more pronounced with $\alpha$-ionone since several oxygenated derivatives at other positions (C-2 and C-3) of the ring (or in the side chain) were formed with $\beta$-ionone. The opposite was reported for P450 BM-3 mutants that selectively produced 4-OH- $\beta$-I, while they contrarily oxidized $\alpha$-ionone to a mixture of four products. $^{12}$ Interestingly, rHinUPO was the UPO that most pronouncedly oxygenated monohydroxyl derivatives further into the corresponding keto derivatives (that are in equilibrium with the gem-diol counterparts formed first). On the other hand, most of the tested UPOs left the C-13 methyl group of both $\alpha$ - and $\beta$-ionone unaffected. Only in the reaction with $\mathrm{rDcaUPO}$, the hydroxylation of the C-13 carbon atom of $\beta$ ionone was observed, producing the interesting EME and 4OH-EME products.

The preference for the hydroxylation of the allylic position in the cyclohexene ring by UPOs was also observed in the reactions with $\alpha$ - and $\beta$-damascones. A strict regioselectivity for this position was especially evident in the reaction of $\alpha$ - damascone with rHinUPO and $\mathrm{rDcaUPO}$, followed by CglUPO, and in the reaction of $\beta$-damascone with $\mathrm{rHinUPO}$ and $C g l$ UPO. Interestingly, in damascones reactions, different regioselectivities with respect to that observed with ionones were ascertained. Therefore, in addition to the cyclohexenyl ring, hydroxylation was produced at the terminal position of the butenoyl side chain, being predominant in AaeUPO reactions but completely absent in $\mathrm{rHinUPO}, \mathrm{rDcaUPO}$, and CglUPO reactions. Thus, the change in the position of the carbonyl and alkene moieties in the butenoyl side chain caused a drastic change in the regioselectivity of AaeUPO toward damascones compared to ionones.

It can be concluded that the oxyfunctionalization of the ionone and damascone isomers catalyzed by UPOs reveal clear advantages over P450 catalysis (e.g., engineered P450 BM-3 variants) due to the higher conversion rates, enzyme stabilities, and little requirements concerning cofactors. These enzymes can therefore be of high interest for the production of valuable compounds of interest for the flavor and fragrance, cosmetic and pharmaceutical industries. However, it is necessary to mention that some current limitations of UPOs, related to their large-scale production and application, still need to be solved for their efficient industrial implementation.

\section{ASSOCIATED CONTENT}

\section{Supporting Information}

The Supporting Information is available free of charge at https://pubs.acs.org/doi/10.1021/acs.jafc.0c01019.

Chemical structures and mass fragmentations of ionones and damascones and their oxygenated derivatives from enzymatic reactions with several UPOs (Table S1); GC-MS analyses of ionones and damascones reactions with several UPOs (Figures S1, S2, S5, and S7); chemical structures of the dihydroxy and keto-hydroxyderivatives from UPO reactions with $\beta$-ionone (Figure S3); and mass spectra and formulae/fragmentations of several oxygenated derivatives of ionones and damascones from reactions with several UPOs (Figures S4, S6, and S8) (PDF)

\section{AUTHOR INFORMATION}

\section{Corresponding Author}

Ana Gutiérrez - Instituto de Recursos Naturales y Agrobiología de Sevilla, CSIC, E-41012 Seville, Spain; 이이.org/00000002-8823-9029; Phone: +34 954624711; Email: anagu@ irnase.csic.es

\section{Authors}

Esteban D. Babot - Instituto de Recursos Naturales y Agrobiología de Sevilla, CSIC, E-41012 Seville, Spain

Carmen Aranda - Instituto de Recursos Naturales y Agrobiología de Sevilla, CSIC, E-41012 Seville, Spain

José C. del Río - Instituto de Recursos Naturales y Agrobiología

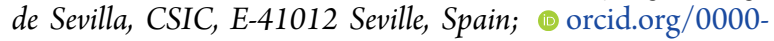
0002-3040-6787

René Ullrich - Department of Bio- and Environmental Sciences, TU Dresden, International Institute Zittau, 02763 Zittau, Germany

Jan Kiebist - JenaBios GmbH, 07749 Jena, Germany

Katrin Scheibner - JenaBios GmbH, 07749 Jena, Germany 
Martin Hofrichter - Department of Bio- and Environmental Sciences, TU Dresden, International Institute Zittau, 02763 Zittau, Germany

Angel T. Martínez - Centro de Investigaciones Biologicas Margarita Salas, CSIC, E-28040 Madrid, Spain; 이이.org/ 0000-0002-1584-2863

Complete contact information is available at: https://pubs.acs.org/10.1021/acs.jafc.0c01019

\section{Funding}

This work was supported by the EnzOx2 (H2020-BBI-PPP2015-2-1-720297) EU-project and the CSIC (201740E071) project.

\section{Notes}

The authors declare no competing financial interest.

\section{ACKNOWLEDGMENTS}

We thank Novozymes A/S (Bagsvaerd, Denmark) for providing the recombinant enzymes ( $\mathrm{rCciUPO}, \mathrm{rHinUPO}$, and $\mathrm{rDcaUPO}$ ) used in this study and A. González-Benjumea for helpful discussion.

\section{REFERENCES}

(1) Serra, S. Recent Advances in the Synthesis of CarotenoidDerived Flavours and Fragrances. Molecules 2015, 20, 12817-12840.

(2) Gerhäuser, C.; Klimo, K.; Hümmer, W.; Hölzer, J.; Petermann, A.; Garreta-Rufas, A.; Böhmer, F. D.; Schreier, P. Identification of 3hydroxy- $\beta$-damascone and related carotenoid-derived aroma compounds as novel potent inducers of Nrf2-mediated phase 2 response with concomitant anti-inflammatory activity. Mol. Nutr. Food Res. 2009, 53, 1237-1244.

(3) Serra, S.; De Simeis, D. Fungi-Mediated Biotransformation of the Isomeric Forms of the Apocarotenoids Ionone, Damascone and Theaspirane. Molecules 2019, 24, 19.

(4) Schoch, E.; Benda, I.; Schreier, P. Bioconversion of $\alpha$-damascone by Botrytis cinerea. Appl. Environ. Microbiol. 1991, 57, 15-18.

(5) Lutz-Wahl, S.; Fischer, P.; Schmidt-Dannert, C.; Wohlleben, W.; Hauer, B.; Schmid, R. D. Stereo- and regioselective hydroxylation of alpha-ionone by Streptomyces strains. Appl. Environ. Microbiol. 1998, 64, 3878-3881.

(6) Gliszczyńska, A.; Gladkowski, W.; Dancewicz, K.; Gabrys, B.; Szczepanik, M. Transformation of $\beta$-damascone to (+)-(S)-4hydroxy- $\beta$-damascone by fungal strains and its evaluation as a potential insecticide against aphids Myzus persicae and lesser mealworm Alphitobius diaperinus Panzer. Catal. Commun. 2016, 80, $39-43$.

(7) Yamazaki, Y.; Hayashi, Y.; Arita, M.; Hieda, T.; Mikami, Y. Microbial Conversion of $\alpha$-Ionone, $\alpha$-Methylionone, and $\alpha$ Isomethylionone. Appl. Environ. Microbiol. 1988, 54, 2354-2360.

(8) Schulz, S.; Girhard, M.; Urlacher, V. B. Biocatalysis: Key to Selective Oxidations. Chem CatChem 2012, 4, 1889-1895.

(9) Khatri, Y.; Girhard, M.; Romankiewicz, A.; Ringle, M.; Hannemann, F.; Urlacher, V. B.; Hutter, M. C.; Bernhardt, R. Regioselective hydroxylation of norisoprenoids by CYP109D1 from Sorangium cellulosum So ce56. Appl. Microbiol. Biotechnol. 2010, 88, 485-495.

(10) Hall, E. A.; Bell, S. G. The efficient and selective biocatalytic oxidation of norisoprenoid and aromatic substrates by CYP101B1 from Novosphingobium aromaticivorans DSM12444. RSC Adv. 2015, 5, 5762-5773.

(11) Appel, D.; Lutz-Wahl, S.; Fischer, P.; Schwaneberg, U.; Schmid, R. D. A P450 BM-3 mutant hydroxylates alkanes, cycloalkanes, arenes and heteroarenes. J. Biotechnol. 2001, 88, 167-171.

(12) Urlacher, V. B.; Makhsumkhanov, A.; Schmid, R. D. Biotransformation of $\beta$-ionone by engineered cytochrome $\mathrm{P} 450$ BM-3. Appl. Microbiol. Biotechnol. 2006, 70, 53-59.
(13) Hofrichter, M.; Kellner, H.; Herzog, R.; Karich, A.; Liers, C.; Scheibner, K.; Wambui, V.; Ullrich, R. Fungal Peroxygenases: A Phylogenetically Old Superfamily of Heme Enzymes with Promiscuity for Oxygen Transfer Reaction. In Grand Challenges in Fungal Biotechnology; Nevalainen, H., Ed.; Springer: Cham, Switzerland, 2020.

(14) Wang, Y.; Lan, D.; Durrani, R.; Hollmann, F. Peroxygenases en route to becoming dream catalysts. What are the opportunities and challenges? Curr. Opin. Chem. Biol. 2017, 37, 1-9.

(15) Hofrichter, M.; Ullrich, R.; Pecyna, M. J.; Liers, C.; Lundell, T. New and classic families of secreted fungal heme peroxidases. Appl. Microbiol. Biotechnol. 2010, 87, 871-897.

(16) Aranda, C.; Ullrich, R.; Kiebist, J.; Scheibner, K.; del Río, J. C.; Hofrichter, M.; Martínez, A. T.; Gutiérrez, A. Selective synthesis of the resveratrol analogue 4,4'-dihydroxy-trans-stilbene and stilbenoids modification by fungal peroxygenases. Catal. Sci. Technol. 2018, 8, 2394-2401.

(17) Gutiérrez, A.; Babot, E. D.; Ullrich, R.; Hofrichter, M.; Martínez, A. T.; del Río, J. C. Regioselective oxygenation of fatty acids, fatty alcohols and other aliphatic compounds by a basidiomycete heme-thiolate peroxidase. Arch. Biochem. Biophys. 2011, 514, 33-43.

(18) Babot, E. D.; del Río, J. C.; Kalum, L.; Martínez, A. T.; Gutierrez, A. Oxyfunctionalization of aliphatic compounds by a recombinant peroxygenase from Coprinopsis cinerea. Biotechnol. Bioeng. 2013, 110, 2332.

(19) Aranda, C.; Olmedo, A.; Kiebist, J.; Scheibner, K.; del Río, J. C.; Martínez, A. T.; Gutiérrez, A. Selective epoxidation of fatty acids and fatty acid methyl esters by fungal peroxygenases. ChemCatChem 2018, 10, 3964-3968.

(20) Olmedo, A.; Aranda, C.; del Río, J. C.; Kiebist, J.; Scheibner, K.; Martínez, A. T.; Gutiérrez, A. From alkanes to carboxylic acids: Terminal oxygenation by a fungal peroxygenase. Angew. Chem., Int. Ed. 2016, 55, 12248-12251.

(21) Peter, S.; Kinne, M.; Wang, X.; Ulrich, R.; Kayser, G.; Groves, J. T.; Hofrichter, M. Selective hydroxylation of alkanes by an extracellular fungal peroxygenase. FEBS J. 2011, 278, 3667-3675.

(22) Babot, E. D.; del Río, J. C.; Cañellas, M.; Sancho, F.; Lucas, F.; Guallar, V.; Kalum, L.; Lund, H.; Gröbe, G.; Scheibner, K.; Ullrich, R.; Hofrichter, M.; Martínez, A. T.; Gutiérrez, A. Steroid hydroxylation by basidiomycete peroxygenases: A combined experimental and computational study. Appl. Environ. Microbiol. 2015, 81, $4130-4142$.

(23) Lucas, F.; Babot, E. D.; Cañellas, M.; del Río, J. C.; Kalum, L.; Ullrich, R.; Hofrichter, M.; Guallar, V.; Martínez, A. T.; Gutiérrez, A. Molecular determinants for selective C25-hydroxylation of vitamins D2 and D3 by fungal peroxygenases. Catal. Sci. Technol. 2016, 6, 288-295.

(24) Babot, E. D.; del Río, J. C.; Kalum, L.; Martínez, A. T.; Gutiérrez, A. Regioselective hydroxylation in the production of 25hydroxyvitamin D by Coprinopsis cinerea peroxygenase. ChemCatChem 2015, 7, 283-290.

(25) Aranda, C.; Municoy, M.; Guallar, V.; Kiebist, J.; Scheibner, K.; Ullrich, R.; del Río, J. C.; Hofrichter, M.; Martínez, A. T.; Gutiérrez, A. Selective synthesis of 4-hydroxyisophorone and 4-ketoisophorone by fungal peroxygenases. Catal. Sci. Technol. 2019, 9, 1398-1405.

(26) Ullrich, R.; Nüske, J.; Scheibner, K.; Spantzel, J.; Hofrichter, M. Novel haloperoxidase from the agaric basidiomycete Agrocybe aegerita oxidizes aryl alcohols and aldehydes. Appl. Environ. Microbiol. 2004, $70,4575-4581$.

(27) Anh, D. H.; Ullrich, R.; Benndorf, D.; Svatos, A.; Muck, A.; Hofrichter, M. The coprophilous mushroom Coprinus radians secretes a haloperoxidase that catalyzes aromatic peroxygenation. Appl. Environ. Microbiol. 2007, 73, 5477-5485.

(28) Gröbe, G.; Ullrich, M.; Pecyna, M. J.; Kapturska, D.; Friedrich, S.; Hofrichter, M.; Scheibner, K. High-yield production of aromatic peroxygenase by the agaric fungus Marasmius rotula. AMB Express 2011, 1, No. 31. 
(29) Kiebist, J.; Schmidtke, K. U.; Zimmermann, J.; Kellner, H.; Jehmlich, N.; Ullrich, R.; Zänder, D.; Hofrichter, M.; Scheibner, K. A peroxygenase from Chaetomium globosum catalyzes the selective oxygenation of testosterone. ChemBioChem 2017, 18, 563-569.

(30) Landvick, S.; Ostergaard, L. H.; Kalum, L. Polypeptides Having Peroxygenase Activity. WO Patent WO2014056916A32016.

(31) Linde, D.; Olmedo, A.; González-Benjumea, A.; Estévez, M.; Renau-Mínguez, C.; Carro, J.; Fernández-Fueyo, E.; Gutiérrez, A.; Martínez, A. T. Two new unspecific peroxygenases from heterologous expression of fungal genes in Escherichia coli. Appl. Environ. Microbiol. 2020, 86, No. e02899-19.

(32) Otey, C. R. High-throughput carbon monoxide binding assay for cytochromes P450. Methods Mol. Biol. 2003, 230, 137-139.

(33) Brenna, E.; Fuganti, C.; Serra, S. Synthesis and olfactory evaluation of the enantiomerically enriched forms of 7,11epoxymegastigma-5(6)-en-9-one and 7,11-epoxymegastigma-5(6)en-9-ols isomers, identified in Passiflora edulis. Tetrahedron: Asymmetry 2005, 16, 1699-1704.

(34) Kitahara, T.; Takagi, Y.; Matsui, M. Novel synthesis of 3hydroxy- $\beta$-damascone, 3 -hydroxydihydro- $\beta$-damascone and $\beta$-damascenone. Agric. Biol. Chem. 1979, 43, 2359-2363.

(35) Mikami, Y.; Fukunaga, Y.; Arita, M.; Kisaki, T. Microbial Transformation of $\beta$-Ionone and $\beta$-Methylionone. Appl. Environ. Microbiol. 1981, 41, 610-617.

(36) More, G. P.; Bhat, S. V. Facile lipase catalysed syntheses of (S)(+)-4-hydroxy- $\beta$-ionone and (S)-(+)-4-hydroxy- $\beta$-damascone: chiral flavorants and synthons. Tetrahedron Lett. 2013, 54, 4148-4149.

(37) Kluge, M.; Ullrich, R.; Scheibner, K.; Hofrichter, M. Stereoselective benzylic hydroxylation of alkylbenzenes and epoxidation of styrene derivatives catalyzed by the peroxygenase of Agrocybe aegerita. Green Chem. 2012, 14, 440-446. 